\title{
Article \\ First Survey of the Vascular and Cryptogam Flora on Bulgaria's Ancient Mounds
}

\author{
Iva Apostolova ${ }^{1, *(\mathbb{D}}$, Desislava Sopotlieva ${ }^{1} \mathbb{D}$, Magdalena Valcheva ${ }^{1} \mathbb{D}$, Anna Ganeva ${ }^{1}$, Veselin Shivarov ${ }^{1} \mathbb{D}$, \\ Nikolay Velev $^{1}$, Kiril Vassilev ${ }^{1}{ }^{(\mathbb{D}}$, Tsvetelina Terziyska ${ }^{1}$ and Georgi Nekhrizov ${ }^{2}$
}

1 Institute of Biodiversity and Ecosystem Research, Bulgarian Academy of Sciences, 2 Gagarin Str., 1113 Sofia, Bulgaria; dsopotlieva@gmail.com (D.S.); magdalena.i.valcheva@gmail.com (M.V.); annaganeva8@gmail.com (A.G.); v.shivarov@abv.bg (V.S.); nikolay.velev@abv.bg (N.V.); kiri15914@abv.bg (K.V.); ts.terziyska@gmail.com (T.T.)

2 National Archaeological Institute with Museum, Bulgarian Academy of Sciences, 2 Saborna Str., 1000 Sofia, Bulgaria; nehrizov@gmail.com

* Correspondence: iva.apostolova@gmail.com

\section{check for} updates

Citation: Apostolova, I.; Sopotlieva,

D.; Valcheva, M.; Ganeva, A.;

Shivarov, V.; Velev, N.; Vassilev, K.; Terziyska, T.; Nekhrizov, G. First Survey of the Vascular and Cryptogam Flora on Bulgaria's Ancient Mounds. Plants 2022, 11, 705. https://doi.org/10.3390/ plants11050705

Academic Editor: Robert Philipp Wagensommer

Received: 11 February 2022

Accepted: 4 March 2022

Published: 6 March 2022

Publisher's Note: MDPI stays neutral with regard to jurisdictional claims in published maps and institutional affiliations.

Copyright: (C) 2022 by the authors. Licensee MDPI, Basel, Switzerland. This article is an open access article distributed under the terms and conditions of the Creative Commons Attribution (CC BY) license (https:// creativecommons.org/licenses/by/ $4.0 /)$.

\begin{abstract}
This work represents the first study of the floristic diversity on Bulgaria's ancient mounds. The objective of this research was to assess the importance of the mounds for the preservation of the native vascular and cryptogam flora. Our sampling design included 111 ancient mounds distributed throughout the country. We recorded a total of 1059 vascular plants, 58 bryophytes and 61 lichen taxa. Despite their small area, the mounds were shown to preserve nearly a quarter of the Bulgarian flora. The vegetation cover on the mounds included $61 \%$ perennials indicating a long-term persistence and stability. The majority (98\%) of the established vascular plants were native species. Although the conservation significance of the vascular plant species were not common, we recorded 2 critically endangered, 9 endangered and 14 Balkan endemics during the present study. The lichen Arthopyrenia salicis was recorded for the first time in Bulgaria and a new locality of the rare bryophyte Ceratodon conicus was discovered. The established compositional difference between plots from the northern and southern slopes of the mounds (88.95\%) is a testament to the high local habitat diversity. The prevalence of species characteristic for Festuco-Brometea suggests that the mounds preserve fragments of native grasslands and steppes. The variation in cover of agricultural and other human modified areas in the mounds' immediate surroundings did not substantially affect their species richness. We argue that the ancient mounds should be taken into consideration in future green space planning.
\end{abstract}

Keywords: bryophytes; generalist plants; grassland specialists; historical monuments; invasive alien plants; kurgans; lichens; native plants

\section{Introduction}

Ancient mounds (also called tumuli or more commonly kurgans) were constructed in temperate Eurasia between 4th millennium BC and 4th century AD and used primarily for burial purposes. A remarkable number of these mounds have been preserved due to their spiritual and cultural importance [1-4]. Bulgaria is exceptionally rich in ancient mounds with a known number of approximately 50,000 [5]; 11,000 of these mounds have been registered in the Archaeological Map of Bulgaria (http:/ / www.naim-bas.com/akb/ accessed on 3 November 2021). Some of Bulgaria's ancient mounds are remarkable historical monuments, including massive underground stone buildings often decorated with wall paintings (e.g., Kazanlak and Aleksandrovo tombs). The most attractive of these structures are important tourist destinations open to the public. At present, most of Bulgaria's ancient mounds are surrounded by vast agricultural lands [4]. Similar to ancient mounds in other European countries, these structures are often standing as sole "islands" of semi-natural vegetation in an otherwise human-modified landscape [3,6,7]. Along with field margins, road verges and buffer strips adjacent to arable land, the ancient mounds preserve small 
semi-natural fragments and provide an opportunity for the long-term survival of indigenous flora. Moreover, ancient mounds consist of different microhabitats, which enrich the suitability for the development of an ecologically diverse flora [8,9]. The long-term persistence of the mounds within agricultural lands, primarily due to sacred and religious respect, naturally makes them a part of the Green and Blue Infrastructure defined at the European level as a "strategically planned network of natural and semi-natural areas with other environmental features designed and managed to deliver a wide range of ecosystem services" [10].

Recently, there has been an increased interest in burial mounds as biodiversity hotspots situated in an otherwise homogenous agricultural landscape [2,3,7,11-15]. Plants, and especially flowering plants (Angiosperms), are one of four groups of living organisms (along with Heteroptera, Symphyta and aculeate Hymenoptera) that have been shown to be best served for the biodiversity evaluation of cultivated areas [16]. Recent research has shown that ancient mounds preserve a remarkable plant diversity $[3,11,13,15,17,18]$. To date, no studies on the natural value of Bulgaria's ancient mounds have been conducted and no records of their floristic diversity are known to exist. At the beginning of the current research, we assumed that the cultural significance and principal sacrosanct nature of Bulgaria's ancient mounds, akin to other countries, provided long-term repository conditions for natural communities and that they served as refugia for indigenous flora in anthropogenically transformed areas. Considering cryptograms' signal for increased degree of community stability and naturalness [19], and in order to enrich the current biodiversity assessment, we included cryptograms (bryophytes and lichens) along with vascular plants in this survey.

The objectives of this study were (1) to collect completely novel information about the floristic diversity of Bulgarian ancient mounds and (2) to assess the potential of ancient mounds to preserve native vascular and cryptogam flora, despite being largely isolated.

\section{Materials and Methods}

\subsection{Study Objects and Study Area}

We used the Archaeological Map of Bulgaria (http:/ /www.naim-bas.com/akb / accessed on 3 December 2021) to select the study objects. Our selection criteria included mounds that were (1) undisturbed by archaeological investigation, (2) were clearly recognizable, and (3) were higher than $1 \mathrm{~m}$ and more than $9 \mathrm{~m}$ in diameter (Table 1). We visited a total of 111 ancient mounds spread out across the territory of Bulgaria (Figures 1 and 2). The mounds were located in the lowlands and hilly plains of the country between 60 and $900 \mathrm{~m}$ a.s.l. In our study, a larger mound base usually corresponded to a larger height. The correlation of height to diameter was $r=0.57518(p<0.05)$ and the correlation of height to 2D area (calculated as $\pi d^{2} / 4$, where " $d$ " is diameter) was $r=0.61815(p<0.05)$. Therefore, we used the $2 \mathrm{D}$ area of the mounds as a representation of the relative mound size.

Table 1. Basic topographic parameters of the studied mounds $(n=111)$.

\begin{tabular}{ccccc}
\hline Parameter & Min & Max & Mean & SD \\
\hline Altitude (m, a.s.l.) & 61.0 & 920.0 & 354.4 & 238.8 \\
Height (m) & 1.2 & 24.5 & 5.3 & 3.1 \\
Diameter (m) & 9.5 & 88.4 & 40.7 & 15.8 \\
Coverage of herbaceous vegetation (\%) & 0 & 100 & 78.3 & 30.5 \\
$\quad$ Coverage of shrub/forest vegetation (\%) & 0 & 100 & 21.7 & 30.5 \\
Surrounding of semi-natural vegetation in 200 m & 0 & 100 & 23.1 & 26.4 \\
$\quad$ buffer (\%) & & & & \\
Surrounding of agricultural and other anthropogenic & 0 & 100 & 76.9 & 26.4 \\
lands in 200 m buffer (\%) & & & & \\
\hline
\end{tabular}




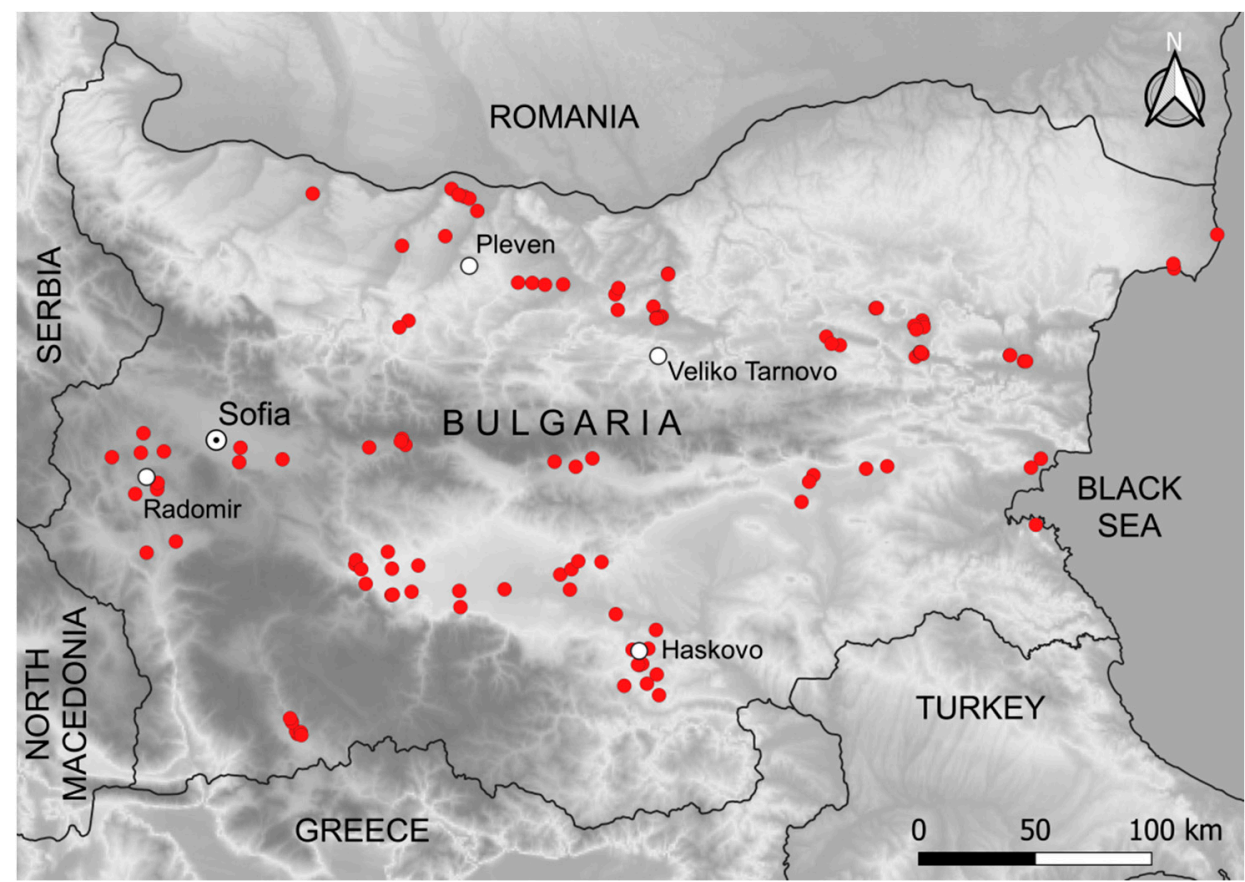

Figure 1. Map of Bulgaria with marked locations of the sampled mounds.

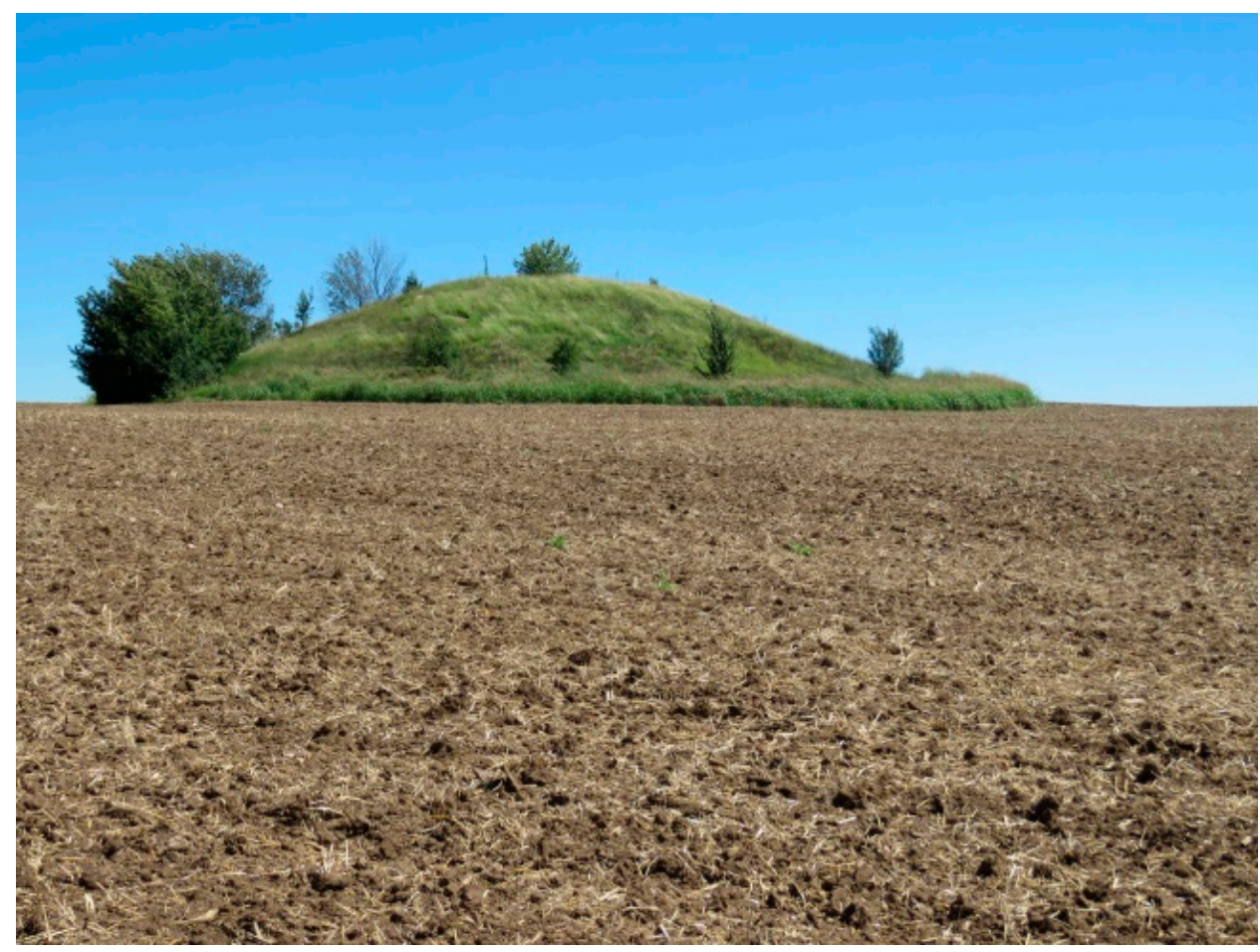

Figure 2. An example of a typical mound view (photo credit: I. Apostolova).

We visually estimated the percentage of grassland and woody vegetation cover of the mounds using Google Earth images. We chose a 10\% threshold to facilitate the rough estimation in vegetation cover of the mounds. There were 86 mounds with more than $70 \%$ herbaceous cover, 16 with more than $70 \%$ forest vegetation cover and 9 with mixed vegetation cover.

In order to estimate the degree of mound isolation, we created a buffer area with a radius of $200 \mathrm{~m}$ around the base of each mound and calculated the land cover of natural vs. non-natural habitats within. The land cover types in the buffer area were obtained 
from the Land Parcel Identification System (LPIS) database maintained by the Ministry of Agriculture, Food and Forestry of Bulgaria and generalized as semi-natural vegetation and agricultural and other anthropogenic lands (for details see [4]). More than half of the studied mounds were highly isolated- 80 mounds were surrounded by more than $70 \%$ of agricultural and other anthropogenic lands.

The investigated mounds fall within the temperate and the continental-Mediterranean climatic zones. The temperate zone, which incorporates the northern parts of the country, has an average mean annual temperature of $11.9^{\circ} \mathrm{C}$ and annual precipitation of $573 \mathrm{~mm}$ (town of Pleven, 1971-2000), while the continental-Mediterranean zone, which is more typical for the southern part of the country, has an average mean annual temperature of $12{ }^{\circ} \mathrm{C}$ and annual precipitation of $637 \mathrm{~mm}$ (town of Haskovo, 1971-2000) [20]. A major part of the study area falls within the broadleaved deciduous forests zone (Map of Natural Vegetation of Europe, [21]), while the southern areas include Mediterranean vegetation fragments with typical plant species [22]. Some small areas in the north-east are influenced by steppe vegetation [23].

\subsection{Sampling Design, Data Collection and Data Analysis}

The field work was conducted during the maximum period for vegetation development (June and July) in 2019 and 2020. Our sampling design was focused on the major ecological differences exhibited at the northern and southern slopes of the mounds. This design considered findings reported by previous studies on burial mounds [9] regarding the difference in floristic composition at different exposures due to habitat heterogeneity. In order to obtain more detailed floristic data, we first sampled all species within $5 \times 5 \mathrm{~m}$ plots situated on the northern and southern slopes (two plots per mound). We then carefully explored the remaining mound area and recorded any additional species until the floristic variety was exhausted. We used presence/absence species data, both at plot and at mound level, for our analyses.

Despite the fact that some taxa were identified to subspecies, we set the final plant list to species level. Some closely related species were joined in species aggregates (Achillea millefolium aggr--including A. millefolium, A. pannonica and A. setacea) or determined at aggregate level (Rubus hirtus aggr.). Plants that were in a phenological stage unsuitable for correct species determination, or that were difficult to identify (e.g., Taraxacum spp.), were determined to genus level. The vascular plant species nomenclature follows The Euro+Med PlantBase [24], with the exception of Brassica juncea, which follows the Plant List [25]. Bryophyte nomenclature follows Hill et al. [26], and lichen nomenclature follows Nimis et al. [27].

For each taxon, we attributed a set of characteristics regarding biological type, functional role, floristic element, conservation and native status (Supplementary ESM S1). Data regarding the biological type of vascular plants were extracted from national literature sources $[28,29]$. The biological types were grouped as follows: short lived (including annual and biannual plants), perennial (including biannual to perennial and perennial plants), dwarf-shrub, shrub and tree. The association of vascular plant species to higher rank syntaxa was defined following Mucina et al. [30]. In cases when more than a single phytosociological class was proposed for a certain diagnostic species, we selected the best representative for the country's vegetation based on our expertise. The diagnostic role of a species was used to assign each species to one of the following 3 functional groups: generalists, grassland specialists and forest specialists. We considered species to be generalists if they were diagnostic of synanthropic vegetation or if they had a broad distribution across different habitat types. The functional affiliation of species that were not assigned to a specific syntaxon was determined based on their most common habitat occurrence in the country. The determination of phytogeographical (floristic) elements for vascular plants follows Assyov and Petrova [31], for bryophytes-Ganeva and Düll [32] and for lichens-Wirth [33] and Nimis [34]. 
The native status of vascular plants was retrieved from Euro+Med PlantBase [24] because of the lack of such data for Bulgaria. Only species listed by Petrova et al. [35] were recognized as invasive alien plants. Vascular plants with conservation importance included Balkan and Bulgarian endemics ([31,36] complemented by The Euro+Med PlantBase [24]), Bulgarian red list species [37], species protected by the Bulgarian legislation (Appendix 3 of the Bulgarian Biological Diversity Act [38]) and other European and international documents (e.g., Council Directive 92/43/EEC [39], as well as the Convention on International Trade in Endangered Species of Wild Fauna and Flora (CITES) [40]). The above mentioned attributes were not applicable for the taxa determined to genus level (N/A). The records of these species were not included in the analyses based on functional groups.

We calculated basic descriptive statistics for all biological characteristics of the registered vascular plants. We used similarity percentages analysis (SIMPER) [41] in PRIMER 7 [42] to determine the species that contributed the most to the floristic resemblances between mounds. The difference in species composition between the mounds was assessed by using the beta diversity index in PAST [43]. We used correlation analyses with Pearson correlation coefficient in STATISTICA 13 [44] to test for correlation between floristic richness (total vascular plant richness, richness of generalists and of grassland and forest specialists) and two other variables: 2D area and proportion of anthropogenic land in the buffer areas. We used plot level data to graphically express the differences in species richness of the different species groups between plots with northern and plots with southern exposure (by their mean values and standard deviation), also carried out in STATISTICA 13 [44].

\section{Results}

\subsection{Diversity and Species Characteristics}

\subsubsection{Vascular Plants}

The list of registered vascular plants includes 1059 taxa (Supplementary ESM S1). The average number of species per mound was $69.9 \pm 22.6 \mathrm{SD}(\min 27, \max 152)$. We identified 971 plants to species level, accepted 3 taxa as aggregates or species groups, and identified 85 taxa to genus level. The floristic diversity was confined to 82 vascular plant families. Flowering plants (Angiosperms) made up the majority of the observed species diversity and only seven species belonged to other groups: one horsetail-Equisetum hyemale, two ferns-Polystichum aculeatum, Pteridium aquilinum, and four Gymnosperms-Juniperus communis, J. oxycedrus, Pinus nigra, $P$. sylvestris. There were 23 families represented by more than 10 taxa, the most species rich of these were Asteraceae-126 taxa (11.9\% of the established taxa), Fabaceae-111 taxa (10.5\%), Poaceae-106 taxa (10\%), Lamiaceae-61 taxa (5.8\%), Brassicaceae-58 taxa (5.5\%), Caryophyllaceae-57 taxa (5.4\%), Rosaceae-48 taxa (4.5\%), Apiaceae-46 taxa (4.3\%), Boraginaceae-31 taxa $(2.9 \%)$ and Plantaginaceae-31 taxa $(2.9 \%)$. Twenty-three other families $(28.1 \%)$ were represented by a single species. The flora of the studied mounds was composed primarily of perennial herbaceous plants (61\%), followed by short-lived plants, and a low number of shrubs and trees. Generalists and grassland specialists dominated the species composition of the mounds. A major part (98\%) of the established vascular plants consisted of native species (Table 2). Only 21 plants belonged to other categories (alien (status unknown) - 13, naturalized alien-5, in large-scale cultivation-2 and doubtfully native-1). Invasive alien plants included Acer negundo, Ailanthus altissima, Amaranthus albus, Conyza canadensis, Cuscuta campestris, Datura stramonium, Erigeron annuus, Phytolacca americana, Robinia pseudoacacia, Sorghum halepense, Xanthium orientale subsp. italicum and X. strumarium. These taxa represent $20 \%$ of all plants included in the list of invasive or potentially invasive alien plants in Bulgaria and three of them (Acer negundo, Ailanthus altissima and Robinia pseudoacacia) are among the "top 10" invasive alien plants in Bulgaria. The largest number of invasive plant species we registered on a single mound was four. The mound (ID 586) was situated in the central part of north Bulgaria (north of the town of Veliko Tarnovo). A substantial number of the studied mounds (40 or $35.4 \%$ ) had at least one invasive alien plant. 
Table 2. Biological characteristics of the registered vascular plants. Total number and descriptive statistics are given.

\begin{tabular}{|c|c|c|c|c|c|}
\hline \multirow[b]{2}{*}{ Parameter } & \multicolumn{5}{|c|}{ On a Mound } \\
\hline & Total & Min & Max & Mean & SD \\
\hline \multicolumn{6}{|l|}{ Biological type } \\
\hline Short-lived & 378 & 4 & 64 & 24.77 & 10.90 \\
\hline Perennial & 495 & 10 & 88 & 36.13 & 13.57 \\
\hline Dwarf-shrub & 17 & 0 & 7 & 0.80 & 1.09 \\
\hline Shrub & 49 & 0 & 12 & 4.02 & 2.80 \\
\hline Tree & 35 & 0 & 7 & 2.55 & 1.87 \\
\hline $\mathrm{N} / \mathrm{A}$ & 85 & 0 & 10 & 2.20 & 2.26 \\
\hline \multicolumn{6}{|l|}{ Plants with conservation importance } \\
\hline Critically Endangered (CR) & 2 & 0 & 1 & 0.04 & 0.19 \\
\hline Endangered (EN) & 9 & 0 & 2 & 0.22 & 0.43 \\
\hline Vulnerable (VU) & 7 & 0 & 2 & 0.15 & 0.39 \\
\hline Near Threatened (NT) & 6 & 0 & 1 & 0.07 & 0.26 \\
\hline Least concern (LC) & 2 & 0 & 2 & 0.21 & 0.45 \\
\hline Bulgarian Biodiversity Act & 10 & & & & \\
\hline Habitat Directive & 1 & & & & \\
\hline CITES & 11 & & & & \\
\hline $\mathrm{N} / \mathrm{A}$ & 85 & 0 & 10 & 2.20 & 2.26 \\
\hline No conservation status & 947 & 27 & 137 & 67.50 & 20.87 \\
\hline \multicolumn{6}{|l|}{ Native status } \\
\hline Native (including archaeophytes) & 948 & 27 & 141 & 66.76 & 21.30 \\
\hline Naturalized alien & 5 & 0 & 2 & 0.15 & 0.39 \\
\hline Doubtfully native & 1 & & & & \\
\hline In large-scale cultivation & 2 & & & & \\
\hline Alien (status unknown) & 13 & 0 & 5 & 0.83 & 0.97 \\
\hline $\mathrm{N} / \mathrm{A}$ & 85 & 0 & 10 & 2.20 & 2.26 \\
\hline No data & 5 & 0 & 2 & 0.45 & 0.63 \\
\hline \multicolumn{6}{|l|}{ Invasive alien plants (for Bulgaria) } \\
\hline Invasive alien plants (IAP) & 12 & 0 & 4 & 0.50 & 0.80 \\
\hline Not classified as IAP & 962 & 27 & 142 & 67.76 & 21.38 \\
\hline $\mathrm{N} / \mathrm{A}$ & 85 & 0 & 10 & 2.20 & 2.26 \\
\hline
\end{tabular}

Critically endangered species present on the mounds included Anchusa stylosa and Limonium asterotrichum. Endangered plants present on the mounds included Astragalus haarbachii, A. wilmottianus, Chamaecytisus frivaldszkyanus, C. kovacevii, Dianthus pallidiflorus, Erysimum cheiranthoides, Festuca thracica, Goniolimon besseranum and Jurinea ledebourii. Fourteen of the registered taxa were Balkan endemics: Achillea clypeolata, A. pseudopectinata, Armeria rumelica, Astragalus wilmottianus, Asyneuma anthericoides, Cytisus eriocarpus, Dianthus moesiacus, Festuca thracica, Heptaptera triquetra, Koeleria simonkaii, Dichoropetalum vittijugum, Polygala supina subsp. rhodopea (syn. P. rhodopaea (Velen.) Janch.), Scabiosa triniifolia and Thymus longidentatus. Eleven plants were included in the CITES Convention. A mound near the town of Radomir (ID 185) contained the richest number of plants of conservation interest and maintained populations of 5 such species.

According to our SIMPER analyses, species composition similarity across plots with northern exposure was $13.25 \%$ and was $11.84 \%$ across plots with southern exposure. We found a remarkable dissimilarity between plots with northern and southern exposure88.95\%. We registered 142 species unique to the plots with southern exposure. Species registered in more than three plots on southern slopes were Camelina sativa, Heliotropium europaeum, Sedum hispanicum, Senecio leucanthemifolius, Valerianella dentata, Verbascum ovalifolium, V. densiflorum, Tribulus terrestris, Crepis sancta, Haplophyllum suaveolens, Herniaria incana, Thymelaea passerina and Filago arvensis. Another 152 species were confined to plots with northern exposure. Taxa that exhibited higher frequency on the plots with northern exposure included Astragalus glycyphylloides, Ficaria verna, Carlina vulgaris, Helleborus odorus, Leucanthemum vulgare, Phlomis tuberosa, Ranunculus polyanthemos, Anthoxanthum odoratum, 
Helictochloa compressa, Quercus frainetto and Luzula campestris. The mean species richness of grassland and forest specialists and generalists was similar between plots with northern and plots with southern exposure (Figure 3).

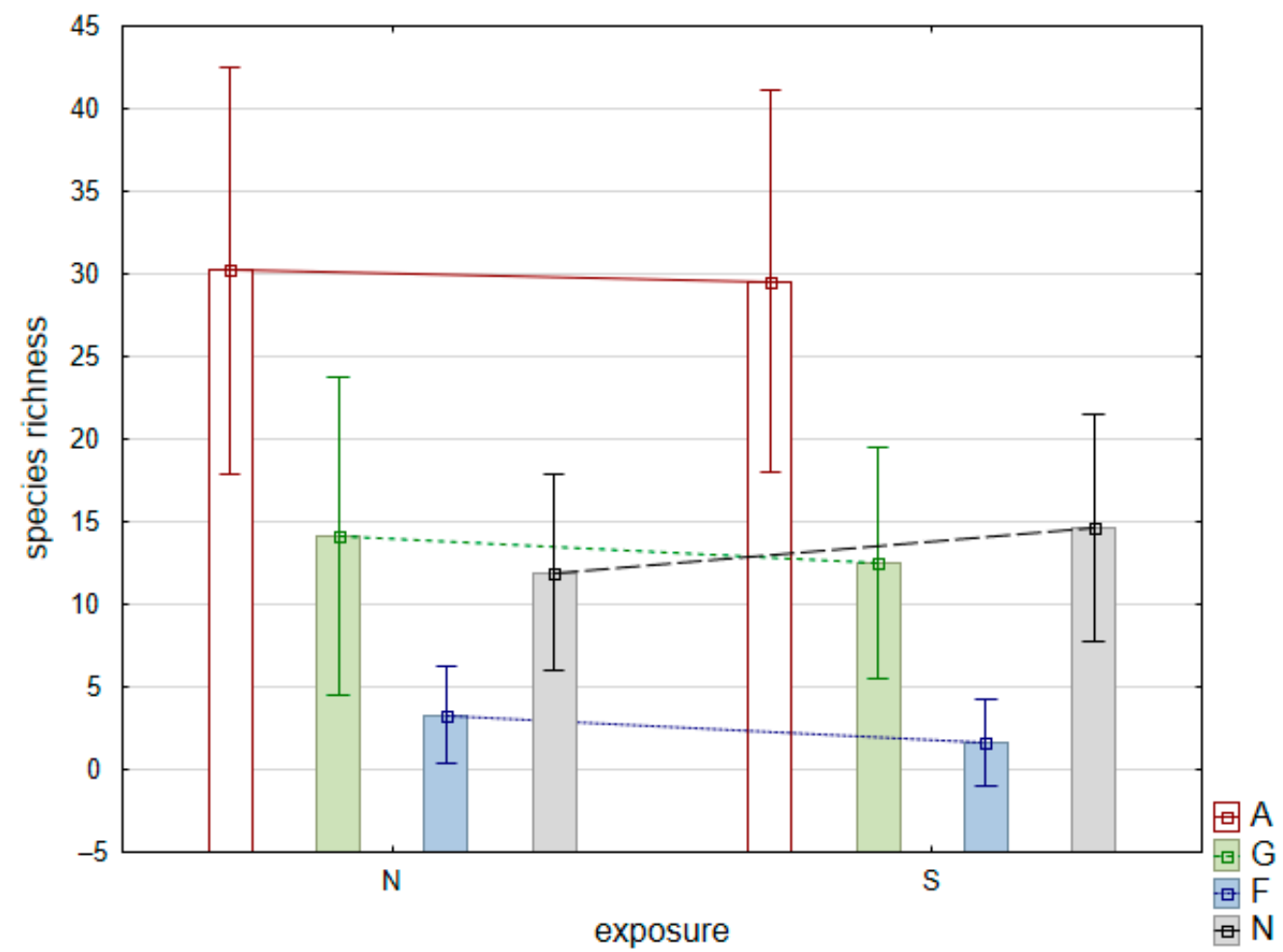

Figure 3. Differences in mean species richness (columns) and standard deviations (whiskers) of different species groups (A-all plant species, G-grassland specialists, F-forest specialists and $\mathrm{N}$-generalists) between plots with northern $(\mathrm{N})$ and plots with southern $(\mathrm{S})$ exposure on the studied mounds.

Average dissimilarity between all pairs of mounds was 0.78 (Whittaker measure for beta diversity). Fifteen species were registered on more than $50 \%$ of the studied objects and included Poa angustifolia (77\% of the studied mounds), Achillea millefolium aggr. (72.6\%), Eryngium campestre (67.3\%), Galium verum (64.6\%), Teucrium chamaedrys (61.1\%), Tragopogon dubius (60.2\%), Sanguisorba minor (54\%) and Botriochloa ischaemum (50.4\%). According to our SIMPER analyses, these taxa along with Prunus spinosa, Lactuca serriola, Dactylis glomerata, Falcaria vulgaris, Convolvulus arvensis, Crataegus monogyna, Elytrigia repens, Galium aparine and Potentilla recta contributed the most to the floristic similarity between mounds. On the other hand, 480 species ( $45.3 \%$ of the total flora) were registered from one or two mounds. We found no relationship between the $2 \mathrm{D}$ area of the mounds and their floristic richness. With the enlargement of the 2D area of the mounds, the richness of forest specialists slightly increased $(r=0.28, p<0.05)$. More than a half of the studied mounds (69) were highly isolated and surrounded by an agricultural matrix above the average in the buffer (Table 1). As the anthropogenically transformed lands around the mounds increased, the total number of registered species $(r=-0.28, p<0.05)$ as well as the total number of specialists $(r=-0.34$, $p<0.05)$, including grassland specialists $(r=-0.33, p<0.05)$, decreased.

The phytogeographical spectrum of the registered plants resembled that of the national flora (Figure 4). The number of species with Mediterranean distribution was the highest, followed by the plants with European and Eurasian distribution. 


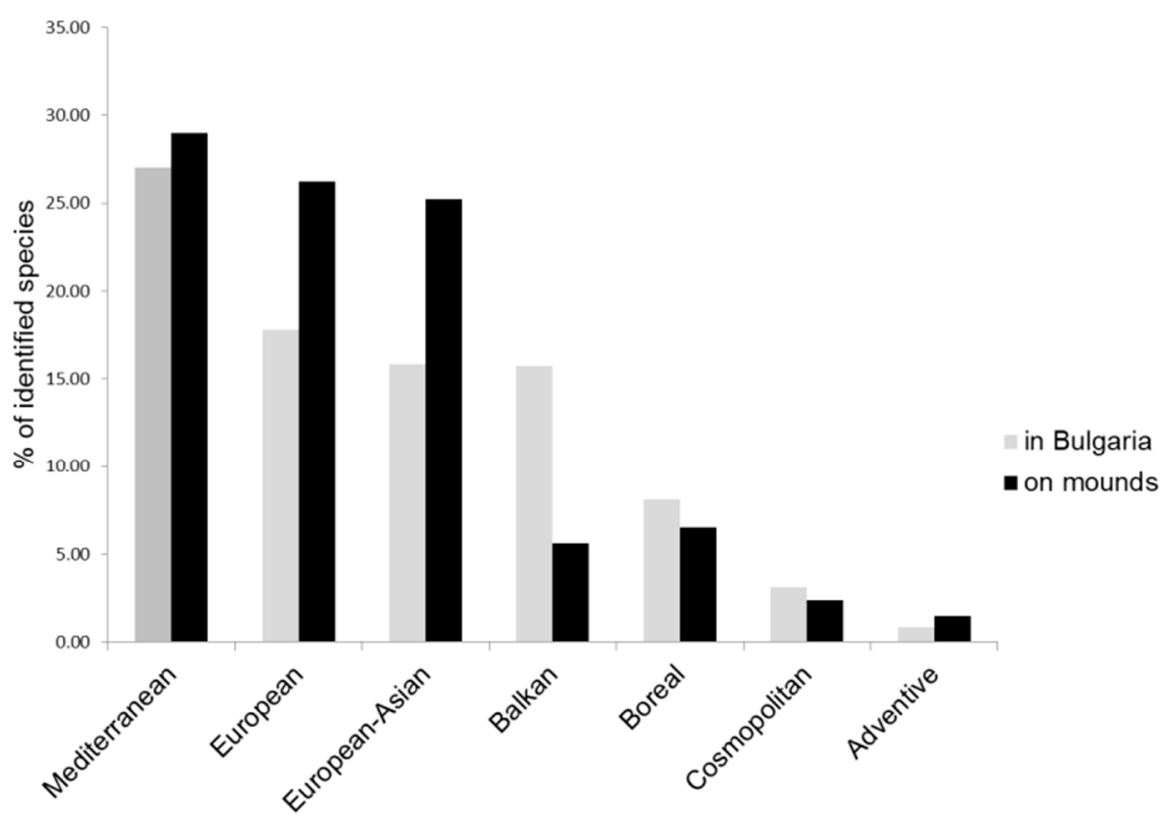

Figure 4. Phytogeographical spectrum of vascular plants on the mounds, compared to vascular plants in the Bulgarian flora. The national record was calculated by following [45].

Across all plants growing on the mounds, 853 were diagnostic of 40 different vegetation classes. Most numerous were the grassland specialists and generalists, and Festuco-Brometea diagnostic species constituted 44\% of all identified plants (Figure 5). There were 193 species diagnostic of anthropogenic vegetation (classes Artemisietea vulgaris, Papaveretea rhoeadis, Chenopodietea, Epilobietea angustifolii, Polygono-Poetea annuae and Sisymbrietea) and their per mound abundance was relatively low (on average from $2.2 \pm 1.8 \mathrm{SD}$ for Chenopodietea to $7.87 \pm 3.5 \mathrm{SD}$ species for Artemisietea vulgaris). There were 100 species diagnostic for forest vegetation (classes Alno glutinosae-Populetea albae, Carpino-Fagetea sylvaticae, Quercetea pubescentis, Quercetea robori-petraeae and Salicetea purpureae). Plants diagnostic for Quercetea pubescentis prevailed with the highest average per mound presence $(2.56 \pm 2.5 \mathrm{SD})$. There were 206 species with wide ecological plasticity to which no diagnostic value toward a particular syntaxon was attributed.

\subsubsection{Bryophytes}

We registered a total of 58 bryophyte taxa; 54 were identified to species level (Supplementary ESM S1). They belong to 39 genera and 16 families. Pottiaceae included the highest number of species, all of which were confined to dry, skeletal and sandy substrates. The second most diverse family was Bryaceae, a group which includes species with diverse ecological preferences. On the mounds, this family was represented by species typical of dry eroded terrains. No bryophytes were registered on 40 of the studied mounds (36.04\%). In cases where bryophytes were found, their number ranged from 1 to 10 species (average $3.1 \pm 2.1 \mathrm{SD}$ ). The only typical epiphytic moss recorded during this study was Orthotrichum pumilum, which was found on trees of the genus Quercus. The rest of the listed species usually occupied the soil substrate and were occasionally also found on woody stems. Abietinella abietina, Barbula unguiculata, Pterygoneurum ovatum, Rhynchostegium megapolitanum and Thuidium assimile were confined to herbaceous habitats. Bryum pallescens has broad ecological affiliation, while Atrichum undulatum, Fissidens taxifolius and Plagiomnium affine were observed only within the forested northern slopes. Nearly all of the bryophytes registered during the present study are taxa commonly found in Bulgaria where they are known to occur in a variety of different plant communities, usually in lowland areas. Phytogeographically, most of the bryophytes ( 35 species) belong to the temperate region. A significant share of the registered bryophytes were cosmopolites (Polytrichum 
juniperinum, Polytrichum piliferum, Funaria hygrometrica, Schistidium apocarpum, Ceratodon purpureus, Weissia controversa, Syntrichia ruralis, Bryum argenteum, Pohlia nutans and Hypnum cupessiforme). The Ceratodon conicus species, previously known from a single locality in Bulgaria (Vitosha Mt. [46]), deserves special attention. This taxon was registered on a mound in the Thracian lowland near the town of Plovdiv (ID249), a substantial distance from the previously reported location.

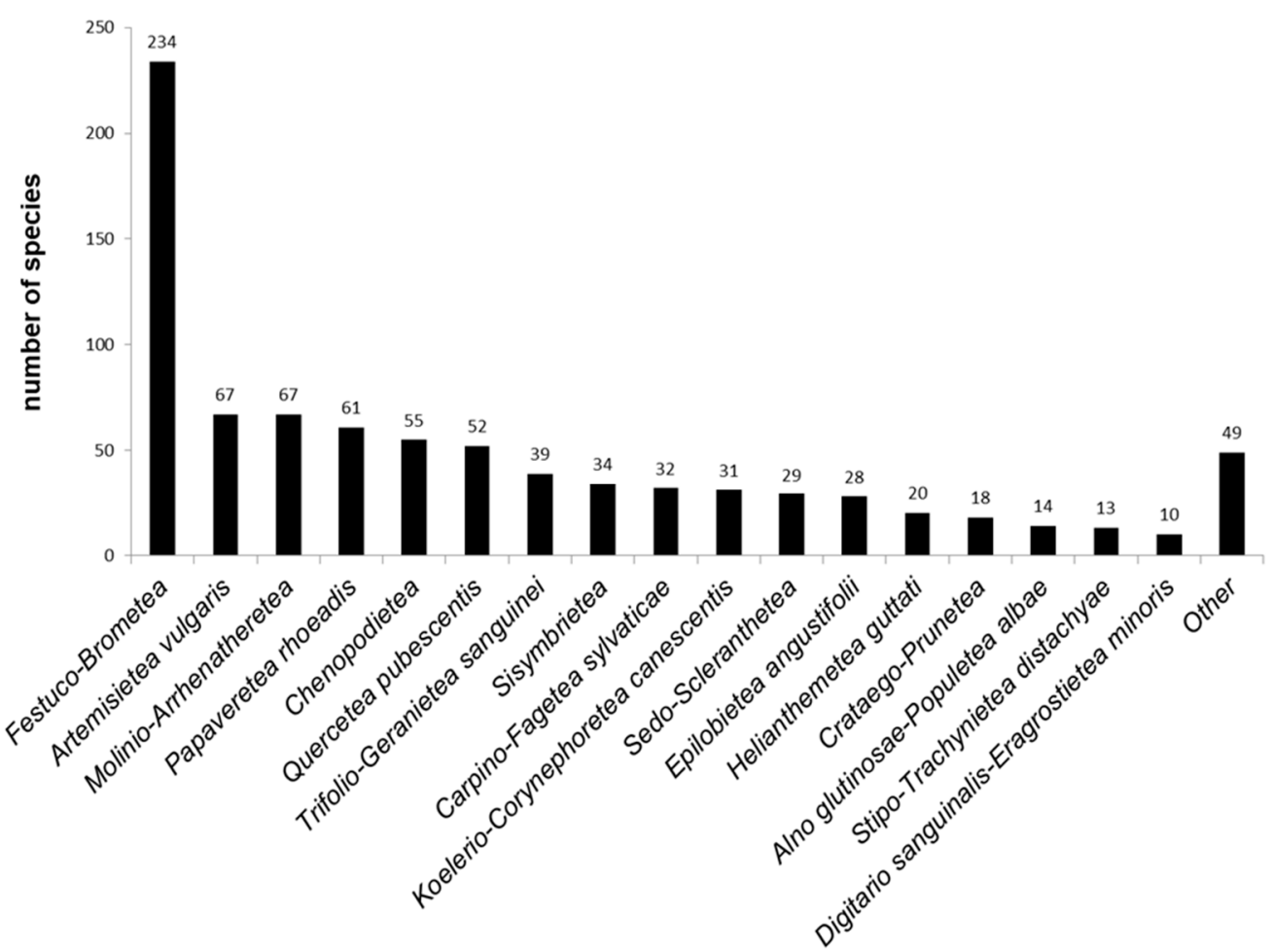

Figure 5. Vascular plants number associated with the phytosociological class level.

\subsubsection{Lichens}

A total of 61 lichen taxa, 56 identified to species level, were registered on $52 \%$ of the studied mounds (Supplementary ESM S1). The highest number of recorded lichens were epiphytes ( 35 taxa), followed by epigean taxa (16 taxa), and by species with wide ecological breadth occurring on all substrate types ( 2 taxa). We recorded eight epilithic lichen taxa. The number of species registered on a mound ranged between 1 and 18 taxa (average $4.0 \pm 2.1 \mathrm{SD}$ ). Lichens were not registered on 57 of the studied mounds. The most common family found on mounds was Parmeliaceae, followed by Cladoniaceae and Physciaceae. Frequently registered lichen species were Xanthoria parietina, Parmelia sulcata and Physcia adscendens. Arthopyrenia salicis is recorded for the first time for the country. Until present, Caloplaca cerinella and Catillaria nigroclavata were known from single Bulgarian localities and are reported here for a second time. Phytogeographically, many of the lichens (31 taxa) are typical for the temperate region. In general, there is a clear preponderance of warmtemperate lichens. Arctic-alpine lichens, common for the Bulgarian alpine and subalpine zones, were not encountered during the present study. It is interesting to note that the new country record and the two other poorly recorded taxa were found together on a single mound (ID 562) situated in the eastern part of the country, near the Black Sea.

\section{Discussion}

\subsection{Species Diversity}

This article presents new information regarding the vascular and cryptogam (bryophytes and lichens) flora of ancient mounds in Bulgaria. The species diversity established during this study is a testament to the importance of ancient mounds for preserving the native 
flora as previously emphasized for other parts of Eurasia [3,12,13,15]. According to the most recent report [47], the Bulgarian flora includes 4064 vascular plant species. The 1056 vascular plant taxa we recorded present nearly a quarter of the overall national plant diversity. These results emphasize the role of ancient mounds in the preservation of a high percentage of the national floristic diversity. Similar results have been previously reported in other European countries: a total of 346 plants were registered on 82 mounds in Hungary [18], which equals $15.5 \%$ of the national floristic diversity [48] and 721 species were registered on 106 mounds in Ukraine [12], which represents 11.6\% of the national flora [49]. The flora of the studied ancient mounds mirrors the phytogeographical characteristics of the Bulgarian flora, i.e., the mounds contain a representative sample of the national plant species pool. The higher proportion of Mediterranean and European, as well as adventive, elements reflects the species pool of the lowlands. A similar finding, namely that ancient mounds reflect local biogeographical zones, was reported by Sudnik-Wójcikowska and Moysiyenko [50], in Ukraine.

We expected that the flora of the mounds in different countries will reflect local environmental conditions, species pools and human influence. Nevertheless, there was a surprising similarity regarding the number of species recorded per mound in different countries. Our results were close to the 72 species registered on the best documented mound, Csípő-halom (Hortobágy, Great Hungarian Plain) [51]. The range of species established per mound in Poland has been found to be from 44 to 81 [52], and the reported number of species per mound in Ukraine has been found to be between 82 and 125 [12]. Similarities among the mounds in Europe did not solely concern their species diversity. Another similarity is the weak correlation between mound area and species richness, originally established by Deák et al. [53]. Our results corroborate these findings and strengthen the idea that mound protection should be of high priority irrespective of their size. Studies of ancient mounds often refer to these structures as islands in a sea of anthropogenically modified areas $[12,14,15]$. This is a fair comparison, given the fact that the increase in agricultural and other modified areas around the mounds does not significantly affect their biodiversity, a finding also confirmed by our study.

The outstanding floristic diversity of Bulgarian mounds, especially given the fact that most of them are located in areas characterized by intensive large-scale agriculture, supports our assumption that ancient mounds are valuable refugia for indigenous flora and that they play an important role in its conservation. The number of species we registered on one or two mounds was high (45.3\% of the established flora) and it reflected the local species pool, a finding similar to that of Sudnik-Wójcikowska and Moysiyenko [8]. The high rate of dissimilarity between the sampled mounds is a reflection of the diversity of biogeographical zones in the country. The difference in species composition between plots with northern and those with southern exposure corresponds to the well-established effect of slope aspect on vegetation [54]. The abundance of generalists on the south facing slopes and the abundance of grassland specialists on the northern slopes support the findings of Deák et al. [9]. Forest specialists are more abundant on north facing slopes due to the ecological requirements of trees to milder climatic conditions and especially to higher air and soil moisture.

According to our results, $6.4 \%$ of the bryophytes native to the country can be found on the mounds. The new Ceratodon conicus locality, established nearly a century later and on a substantial distance away from the original locality, gives us a reason to believe in the potential of ancient mounds for the long-term preservation of biodiversity. The cover and diversity of lichen species depends primarily on suitable substrates and environmental factors. Although the saxicolous lichens represent one of the largest ecological groups of lichens, their preferred bare and stable rock substrates were not found on the studied mounds. Most of the saxicolous lichens found during this study appeared on artificial substrates of contemporary anthropogenic structures, such as geodetic points. Only a few species were found on pebbles that are not a suitable substrate for lichens because of their instability. The predominance of epiphytic lichens is not surprising as most of 
the mounds had trees and shrubs. The terricolous taxa were rarely present due to their inability to compete with the well-established vegetation. The first record of the epiphytic lichen Arthopyrenia salicis from Bulgaria is noteworthy. To our knowledge, the closest A. salicis locality is in the Slovenian Julian Alps [55]. This species is especially frequent in northern and western Europe [56], where it occurs on the smooth bark of the trees, as experienced in our study. Lichens frequently established on the mounds are among the most common species characteristic of the lowland epiphytic communities on broadleaved trees in Bulgaria. However, the abundance of Xanthoria parietina and Physcia adscendens is indicative of a higher load of nitrogenous compounds [57]. Typical nitrophilous lichen community members, such as Phaeophyscia orbicularis and Polycauliona polycarpa [58], were also relatively frequently found on the studied mounds. We assume that these nitrophilous species might have been positively affected by the surrounding agricultural lands and treated with fertilizers.

\subsection{Species Characteristics}

The ecological characteristics of the established flowering plants strongly resemble the peculiarities of the national flora with a dominant presence of species typical for dry areas. These species use evolutionary advantages to survive via vegetative propagules (e.g., Agropyron repens, Poa angustifolia, Botryochloa ischaemum, Achillea millefolium, Bryum dichotomum, B. klinggraeffii, B. moravicum, B. rubens and B. ruderale), underground storage organs (e.g., Arum maculatum, Crocus flavus and Ornithogalum spp.) or via annual life cycles (e.g., Trifolium striatum, Astragalus spruneri, Apera spica-venti, Arenaria serpyllifolia and Coronilla scorpioides). Patches of bare ground and pits left after continuous illegal treasure hunting become suitable places where fruits or seeds of common trees and shrubs (Pyrus pyraster, Prunus cerasifera, P. spinosa) accidentally fall and develop free from competition. Open spaces also favor the establishment and continued persistence of certain bryophytes confined to eroded habitats (Ceratodon purpureus, Polytrichim piliferum and Bryum argenteum).

The role of ancient mounds in steppe preservation is continuously being reiterated in the published literature $[3,6,7,17,59]$. Our study confirms the prevalence of species characteristic of the Festuco-Brometea class associated with the mounds, similar to those reported for Ukraine [6]. This vegetation type includes dry grasslands and steppes from the sub-Mediterranean, nemoral and hemiboreal areas of Europe [30]. Festuco-Brometea is widespread in the lowlands and hilly plains of Bulgaria and unites mainly secondary herbaceous communities. Some exceptions occur in the north-eastern parts of the country where small fragments of true steppe communities are present. Given the anthropogenic origin of the mounds, a large number of anthropophytes are logically expected to be associated with these structures. We identified $19.9 \%$ of all species as related to anthropogenic vegetation of the classes Artemisietea vulgaris, Papaveretea rhoeadis and Sisymbrietea. Species characteristic of Artemisietea vulgaris provide a signal for ruderalization associated with dry habitats. Species diagnostic of Papaveretea rhoeadis and Sisymbrietea reveal the apparent influence of segetal vegetation in the mounds' immediate vicinity. The diagnostic features of the plant taxa registered on the mounds gives us a reason to characterize most of their vegetation as ruderalized steppes. Although the ancient mounds are considered to be important areas for the protection of steppe flora and vegetation [3], in Bulgaria they also preserve fragments of forest communities [4] characteristic of temperate lowlands. Most of the established trees and shrubs belong to Quercetea pubescentis and Carpino-Fagetea sylvaticae, two classes widely distributed on the territory of the country. The development of trees, which were visibly old in some places, is a result of the natural succession directed toward the potential vegetation of the Bulgarian lowlands under temperate climate [21]. This successional trend is also indicative of the apparent lack of management practices and activities as associated with the ancient mounds. The diversity of tree species and forest specialists was low compared to the overall floristic diversity. However, the increasing tree coverage leads to a decreased biodiversity under the canopy [60]. 


\subsection{Significance for Nature Conservation}

Preserved for 2-3 millennia, ancient mounds retain the natural flora as evidenced by the predominant presence of native species associated with these structures. The prevalence of perennials is a testament to the long-lasting stability of the local vegetation and creates conditions for the establishment of cryptogams. The lack of serious disturbances over prolonged periods, excluding archaeological investigations and damaging activities by treasure hunters, has favored the establishment of perennial species, respective of closed vegetation, which prevents the penetration of many neophytes and especially that of invasive alien plants. The common development of communities in vascular plants and cryptogams is considered an indication of sustainability [61].

Vascular plants of conservation importance were not common on the ancient mounds. The observed endemic species presented only 5.2\% of the Balkan endemics reported for Bulgaria [36]. The sampled mounds preserve two critically endangered and nine endangered plants, which represent $1.8 \%$ of both categories evaluated at the national level [37].

Our results corroborate the notion that the undisturbed closed vegetation prevents establishment of alien invasive plants [62]. The presence of low neophytes and alien plant numbers has been previously reported for other archaeological sites [63]. Nevertheless, our results hint towards an impending threat given the proportion of mounds affected by the presence of even sole individuals of alien plant species. Although the presence of large agricultural fields isolates the mounds from immediate human influence, we found no evident relationship between the surrounding land use and the number of anthropophytes present on the mounds. Similar results were previously reported by Sudnik-Wójcikowska and Moysiyenko [64].

The existence of relatively well-preserved floristic diversity indicates that the mounds have the potential to provide not only cultural and spiritual but also other valuable ecosystem services (e.g., provisioning of biomass, maintenance of native plant populations and maintenance of physical, chemical and biological conditions of the locality) [65], which, in the face of accelerated fragmentation and land degradation, will become even more important in the future. Therefore, there is a clear need for further research on the topic. The high rate of isolation on the mounds along with their floristic richness, emphasize their remarkable role in the preservation of natural communities, and in providing connectivity when serving as stepping stones for species dispersal from and to other fragments of natural and semi-natural environments, as previously mentioned by others [7].

The Natura 2000 and the network of protected areas are naturally considered as part of the EU's strategy for green and blue infrastructure, but new areas are expected to be added in the future [10]. Within the growing body of literature regarding the concept of green infrastructure, we perceive green infrastructure as green space planning [66]. Situated in anthropogenically transformed lands, the mounds present ideal features for greenspace preservation. Some of Bulgaria's ancient mounds are situated within urban areas, but we did not include them in our sampling. The presence of semi-natural (green) space within arable fields will certainly support an increase in environmental benefits. Ancient mounds are existing structures that only need maintenance and protection. Protection from further treasure hunting is required because such disturbances could facilitate the penetration of alien and woody plants. Reduction of shrubs (especially Prunus spinosa) and non-native trees (Robinia pseudoacacia, Ailanthus altissima) will help to maintain species-rich grasslands. Although species of conservation importance were rarely observed during our study, the mounds should not be neglected as important areas for plant protection, especially in the cases of highly fragmented semi-natural areas where different subpopulations are well separated from each other.

\section{Conclusions}

Millennia-old ancient mounds are a characteristic feature of the Bulgarian landscape and play an important role for the conservation of indigenous flora. Agricultural practices in the surrounding areas have little effect on the floristic richness of the mounds. In this 
study, we show that Bulgaria's ancient mounds preserve a considerable proportion of the national vascular and cryptogam flora. Further research will certainly offer new knowledge about the natural significance of the ancient mounds. Current legal preservation of the ancient mounds as archaeological monuments does not guarantee their proper management in terms of nature conservation. With the enlargement of the green infrastructure in the cultural landscape at European level, the significance of ancient mounds will most certainly increase.

Supplementary Materials: The following supporting information can be downloaded at: https: / / www.mdpi.com/article/10.3390/plants11050705/s1. ESM S1: Original floristic data from 111 ancient mounds from Bulgaria.

Author Contributions: Conceptualization I.A.; methodology I.A. and D.S.; data collection I.A., D.S. M.V., N.V., K.V., A.G., T.T. and V.S.; formal analysis I.A., M.V. and D.S.; original draft preparation I.A., A.G. and V.S.; review and editing M.V., D.S. and G.N. All authors have read and agreed to the published version of the manuscript.

Funding: This research was funded by the Bulgarian National Science Fund (contract КП-06$\mathrm{H} 21 / 2$, 2018).

Informed Consent Statement: Not applicable.

Data Availability Statement: All data analyzed in this study are available in Supplementary ESM S1.

Acknowledgments: We wish to thank Balazs Deák for his inspiration to begin studying mounds in Bulgaria. We also thank Salza Palpurina for her help during the field work. We would like to acknowledge Kaloyan Ivanov, who kindly polished the English in this paper.

Conflicts of Interest: The authors declare no conflict of interest. The funders had no role in the design of the study; in the collection, analyses, or interpretation of data; in the writing of the manuscript, or in the decision to publish the results.

\section{References}

1. Sudnik-Wójcikowska, B.; Moysiyenko, I.I. Kurhany na "Dzikich Polach"—Dziedzictwo Kultury i Ostoja Ukraińskiego Stepu [Kurgans in the "Wild Field"-A Cultural Heritage and Refugium of the Ukrainian Steppe]; Wydawnictwa Uniwersytetu Warszawskiego: Warsaw, Poland, 2012.

2. Deák, B. Nature and Culture: The Role of Ancient Burial Mounds in the Conservation of Eurasian Steppe Vegetation; Centre for Ecological Research: Tihany, Hungary, 2020; p. 172.

3. Deák, B.; Tóthmérész, B.; Valkó, O.; Sudnik-Wójcikowska, B.; Moysiyenko, I.; Bragina, T.; Apostolova, I.; Dembicz, I.; Bykov, N.; Török, P. Cultural monuments and nature conservation: A review of the role of kurgans in the conservation and restoration of steppe vegetation. Biodivers. Conserv. 2016, 25, 2473-2490. [CrossRef]

4. Apostolova, I.; Palpurina, S.; Sopotlieva, D.; Terziyska, T.; Velev, N.; Vassilev, K.; Nekhrizov, G.; Tsvetkova, N. Ancient Burial Mounds-Stepping Stones for Semi-Natural Habitats in Agricultural Landscape. Ecol. Balk. 2020, 12, 43-52.

5. Kitov, G. The Thracian tumuli. Thracia 1993, 10, 39-80.

6. Sudnik-Wójcikowska, B.; Moysiyenko, I.I. The Flora of Kurgans in the West Pontic Grass Steppe Zone of Southern Ukraine. Chornomorski Bot. J. 2006, 2, 14-44. Available online: http://eKhSUIR.kspu.edu/handle/123456789/2868 (accessed on 5 February 2022). [CrossRef]

7. Dembicz, I.; Moysiyenko, I.; Shaposhnikova, A.; Vynokurov, D.; Kozub, L.; Sudnik-Wójcikowska, B. Isolation and patch size drive specialist plant species density within steppe islands: A case study of kurgans in southern Ukraine. Biodivers. Conserv. 2016, 25, 2289-2307. [CrossRef]

8. Sudnik-Wójcikowska, B.; Moysiyenko, I.I. The floristic differentiation of microhabitats within kurgans in the desert steppe zone of southern Ukraine. Acta Soc. Bot. Pol. 2008, 77, 139-147. [CrossRef]

9. Deák, B.; Kovács, B.; Rádai, Z.; Apostolova, I.; Kelemen, A.; Kiss, R.; Lukács, K.; Palpurina, S.; Sopotlieva, D.; Báthori, F.; et al. Linking environmental heterogeneity and plant diversity: The ecological role of small natural features in homogeneous landscapes. Sci. Total Environ. 2021, 763, 144199. [CrossRef]

10. European Commission. Green Infrastructure (GI)-Enhancing Europe's Natural Capital, Communication from the Commission to the European Parliament, the Council, the European Economic and Social Committee and the Committee of Regions. 2013. Available online: https:/ / eur-lex.europa.eu/legal-content/EN/TXT/?uri=CELEX:52013DC0249 (accessed on 19 July 2021).

11. Moysiyenko, I.; Zachwatowicz, M.; Sudnik-Wójcikowska, B.; Jabłońska, E. Kurgans help to protect endangered steppe species in the Pontic grass steppe zone, Ukraine. Wulfenia 2014, 21, 83-94. 
12. Sudnik-Wójcikowska, B.; Moysiyenko, I.I.; Zachwatowicz, M.; Jabłońska, E. The value and need for protection of kurgan flora in the anthropogenic landscape of steppe zone in Ukraine. Plant Biosyst. 2011, 145, 638-653. [CrossRef]

13. Deák, B.; Tölgyesi, C.; Kelemen, A.; Bátori, Z.; Gallé, R.; Bragina, T.M.; Yerkin, A.I.; Valkó, O. The effects of micro-habitats and grazing intensity on the vegetation of burial mounds in the Kazakh steppes. Plant Ecol. Divers. 2017, 10, 509-520. [CrossRef]

14. Deák, B.; Valkó, O.; Nagy, D.D.; Török, P.; Torma, A.; Lőrinczi, G.; Kelemen, A.; Nagy, A.; Bede, Á.; Mizser, S.; et al. Habitat islands outside nature reserves-Threatened biodiversity hotspots of grassland specialist plant and arthropod species. Biol. Conserv. 2020, 241, 108254. [CrossRef]

15. Dembicz, I.; Moysiyenko, I.I.; Kozub, Ł.; Dengler, J.; Zakharova, M.; Sudnik-Wójcikowska, B. Steppe islands in a sea of fields: Where island biogeography meets the reality of a severely transformed landscape. J. Veg. Sci. 2021, 32, e12930. [CrossRef]

16. Duelli, P.; Obrist, M.K. In search of the best correlates for local organismal biodiversity in cultivated areas. Biodivers. Conserv. 1998, 7, 297-309. [CrossRef]

17. Sudnik-Wójcikowska, B.; Moysiyenko, I.I. Ukrainian kurgans as refugia of steppe flora and their role in steppe restoration. In Steppenlebensräume Europas_Gefährdung, Erhaltungsmaßnahmen und Schutz; Baumbach, H., Pfützenreuter, S., Eds.; Thüringer Ministerium für Landwirtschaft, Forsten, Umwelt und Naturschutz: Erfurt, Germany, 2013; pp. 201-210.

18. Deák, B.; Valkó, O.; Török, P.; Kelemen, A.; Bede, Á.; Csathó, A.I.; Tóthmérész, B. Landscape and habitat filters jointly drive richness and abundance of specialist plants in terrestrial habitat islands. Landsc. Ecol. 2018, 33, 1117-1132. [CrossRef]

19. Czerepko, J.; Gawryś, R.; Szymczyk, R.; Pisarek, W.; Janek, M.; Haidt, A.; Kowalewska, A.; Piegdoń, A.; Stebel, A.; Kukwa, M.; et al. How sensitive are epiphytic and epixylic cryptogams as indicators of forest naturalness? Testing bryophyte and lichen predictive power in stands under different management regimes in the Białowieża forest. Ecol. Indic. 2021, 125, 107532. [CrossRef]

20. Velev, S. Climatic regioning. In Geography of Bulgaria; Kopralev, I., Ed.; Publishing House ForCom: Sofia, Bulgaria, 2002; pp. 155-156.

21. Bohn, U.; Golub, G.; Hettwer, C. (Eds.) Karte der Naturlichen Vegetation Europas. Legende/Map of the Natural Vegetation of Europe, Part 2: Legend (German/English); Bundesamt für Naturschutz: Bonn, Germany, 2003.

22. Meshinev, T. Vegetation and phytogeography: A brief characteristic. In Biogeography and Ecology of Bulgaria; Monographie Biologicae; Fet, V., Popov, A., Eds.; Springer: Dordrecht, The Netherlands, 2007; Volume 82, pp. 581-588.

23. Tzonev, R.; Roussakova, V.; Dimitrov, M. The Western-Pontic steppe vegetation in Bulgaria. Hacquetia 2006, 5, 5-23.

24. Euro+Med. Euro+Med-The Information Resource for Euro-Mediterranean Plant Diversity. 2006-2021. Available online: http:/ / ww2.bgbm.org/EuroPlusMed/ (accessed on 20 September 2021).

25. The Plant List. Version 1.1. 2013. Available online: http:/ / www.theplantlist.org/ (accessed on 1 September 2021).

26. Hill, M.O.; Bell, N.; Bruggeman-Nannenga, M.A.; Brugués, M.; Cano, M.J.; Enroth, J.; Flatberg, K.I.; Frahm, J.-P.; Gallego, M.T.; Garilleti, R.; et al. An annotated checklist of the mosses of Europe and Macaronesia. J. Bryol. 2006, 28, 198-267. [CrossRef]

27. Nimis, P.L.; Hafellner, J.; Roux, C.; Clerc, P.; Mayrhofer, H.; Martellos, S.; Bilovitz, P.O. The lichens of the Alps - an annotated checklist. MycoKeys 2018, 31, 1-634. [CrossRef] [PubMed]

28. Flora of Republic of Bulgaria; Academic Publishing "Prof. Marin Drinov": Sofia, Bulgaria, 2012.

29. Delipavlov, D.; Cheshmedzhiev, I.; Popova, M.; Terziyski, D.; Kovachev, I. Guide to Vascular Plants in Bulgaria; Academic Publishing of the Agricultural University: Plovdiv, Bulgaria, 2003.

30. Mucina, L.; Bültmann, H.; Dierßen, K.; Theurillat, J.P.; Raus, T.; Čarni, A.; Šumberová, K.; Willner, W.; Dengler, J.; García, R.G.; et al. Vegetation of Europe: Hierarchical floristic classification system of vascular plant, bryophyte, lichen and algal communities Appl. Veg. Sci. 2016, 19, 3-264. [CrossRef]

31. Assyov, B.; Petrova, A. (Eds.) Conspectus of the Bulgarian Vascular Flora. Distribution Maps and Floristic Elements; Bulgarian Biodiversity Foundantion: Sofia, Bulgaria, 2012.

32. Ganeva, A.; Düll, R. A contribution to the Bulgarian bryoflora. Checklist of Bulgarian bryophytes. In Contributions to the Bryoflora of Former Yugoslavia and Bulgaria; Düll, R., Ganeva, A., Martincic, A., Pavletic, Z., Eds.; IDH: Bad Münstereifel, Germany, 1999; pp. 111-199.

33. Wirth, V. Die Flechten Baden-Württemmbergs; E. Ulmer GMBH Co: Stuttgart, Germany, 1995.

34. Nimis, P.L. ITALIC - The Information System on Italian Lichens; Version 6.0; University of Trieste, Department of Biology: Berlin, Germany, 2016; Available online: http:/ / dryades.units.it/italic (accessed on 1 August 2021).

35. Petrova, A.; Vladimirov, V.; Georgiev, V. Invasive Alien Plant Species in Bulgaria; Institute of Biodiversity and Ecosystem Research, BAS: Sofia, Bulgaria, 2012

36. Petrova, A.; Vladimirov, V. Balkan endemics in the Bulgarian flora. Phytol. Balc. 2010, 16, 293-311.

37. Petrova, A.; Vladimirov, V. Red list of Bulgarian vascular plants. Phytol. Balc. 2009, 15, 63-94.

38. Biological Diversity Act. State Gazette, Sofia, Issue 77, August 2002, Last Change and Addition Issue 58, July 2016. Available online: http:/ / eea.government.bg/bg/legislation/biodiversity/ZBR_en_26_07_2016.pdf (accessed on 27 October 2021).

39. Council Directive 92/43/EEC of 21 May 1992 on the Conservation of Natural Habitats and of Wild Fauna and Flora. OJ L 206. 22 July 1992, pp. 7-50. Available online: https:/ / eur-lex.europa.eu/legal-content/EN/TXT/?uri=CELEX:31992L0043 (accessed on 22 February 2021).

40. Convention on International Trade in Endangered Species of Wild Fauna and Flora (CITES), 1973. Signed at Washington, D.C.; on 3 March 1973, Amended at Bonn, on 22 June 1979, Amended at Gaborone, on 30 April 1983. Available online: https:// checklist.cites.org/\#/en (accessed on 1 September 2021). 
41. Clarke, K.R. Non-parametric multivariate analyses of changes in community structure. Austral. Ecol. 1993, 18, 117-143. [CrossRef]

42. PRIMER-E Ltd. PRIMER (Plymouth Routines In Multivariate Ecological Research), Version 7. 2017. Available online: http: //www.primer-e.com (accessed on 19 December 2021).

43. Hammer, Ø.; Harper, D.; Ryan, P. PAST: Paleontological Statistics Software Package for Education and Data Analysis. Palaeontol. Electron. 2001, 4. Available online: https:/ /www.nhm.uio.no/english/research/infrastructure/past/ (accessed on 18 January 2022).

44. Dell Inc. Dell Statistica (Data Analysis Software System), Version 13. 2016. Available online: http:/ / www.dell.com (accessed on 18 January 2022).

45. Peev, D.; Delcheva, M. Florogeographical elements and evolutionary trends in the Bulgarian Flora. In Biogeography and Ecology of Bulgaria; Monographie Biologicae; Fet, V., Popov, A., Eds.; Springer: Dordrecht, The Netherlands, 2007; Volume 82, pp. 571-579.

46. Arnaudov, N. The Moss Flora of Vitosha Mt; Ann. de l'Universite de Sofia: Sofia, Bulgaria, 1908; Volume 3-4, pp. 1-37.

47. Petrova, A.; Vladimirov, V. Recent progress in floristic and taxonomic studies in Bulgaria. Bot. Serb. 2018, 42, 35-69. [CrossRef]

48. Bartha, D.; Király, G.; Schmidt, D.; Tiborcz, V.; Barinza, Z.; Csiky, J.; Jakab, G.; Lesku, B.; Schmotzer, A.; Vidéki, R.; et al. (Eds.) Magyarország Edényes Növényfajainak Elterjedési Atlasza [Distribution Atlas of Vascular Plants of Hungary; Nyugat-magyarországi Egyetem Kiadó/University of West Hungary: Sopron, Hungary, 2015.

49. Mosyakin, S.L.; Fedoronchuk, N.M. Vascular Plants of Ukraine: A Nomenclatural Checklist; National Academy of Sciences of Ukraine-MG Kholodny Institute of Botany: Kyiv, Ukraine, 1999.

50. Sudnik-Wójcikowska, B.; Moysiyenko, I. Zonal character of the flora of kurgans in central and southern Ukraine. Biodiv. Res. Conserv. 2010, 17, 47-52. [CrossRef]

51. Barczi, A. Data for the botanical and pedological surveys of the Hungarian kurgans (Great Hungarian Plain, Hortobágy). Thaiszia J. Bot. 2003, 13, 113-126.

52. Cwener, A. Ros 'liny naczyniowe kurhano'w w dorzeczu dolnej Szreniawy i Nidzicy (Wy_zyna Małopolska, południowa Polska) [The vascular plants of the mounds in the lower Szreniawa and Nidzica river-basin (Małopolska Upland, South Poland)]. Fragm. Florist. Geobot. Pol. 2004, 11, 27-40.

53. Deák, B.; Valkó, O.; Török, P.; Tóthmérész, B. Factors threatening grassland specialist plants-A multi-proxy study on the vegetation of isolated grasslands. Biol. Conserv. 2016, 204, 255-262. [CrossRef]

54. Erdős, L.; Méri, A.; Bátori, Z.; Gallé, R.; Kőrmőczi, L. North-south facing vegetation gradients in the Villány Mountains: A case study on the population and the community level. Pak. J. Bot. 2012, 44, 927-932.

55. Batič, F.; Primožič, K.; Surina, B.; Trošt, T.; Mayrhofer, H. Contributions to the lichen flora of Slovenia X. Lichens from the Slovenian Julian Alps. Herzogia 2003, 16, 143-154.

56. Coppins, B.J.; Orange, A. Arthopyrenia A. Massal. In The lichens of Great Britain and Ireland, 2nd ed.; Smith, C.W., Aptroot, A., Coppins, B.J., Fletcher, A., Gilbert, O.L., James, P.W., Wolseley, P.A., Eds.; The British Lichen Society: London, UK, 2009; pp. 136-138.

57. Richardson, D.H.S. Pollution Monitoring with Lichens. Naturalists' Handbooks 19; The Richmond Publishing: Slough, UK, 1992.

58. van Haluwyn, C.; van Herk, C.M. Bioindication: The community approach. In Monitoring with Lichens-Monitoring Lichens; Nimis, P.L., Scheidegger, C., Wolseley, P., Eds.; Kluwer Academic: Dordrecht, The Netherlands, 2002; pp. 39-64.

59. Valkó, O.; Zmihorski, M.; Biurrun, I.; Loos, J.; Labadessa, R.; Venn, S. Ecology and conservation of steppes and semi-natural grasslands. Hacquetia 2016, 15, 5-14. [CrossRef]

60. Teleki, B.; Sonkoly, J.; Erdős, L.; Tóthmérész, B.; Prommer, M.; Török, P. High resistance of plant biodiversity to moderate native woody encroachment in loess steppe grassland fragments. Appl. Veg. Sci. 2020, 23, 175-184. [CrossRef]

61. Boch, S.; Müller, J.; Prati, D.; Fischer, M. Low-intensity management promotes bryophyte diversity in grasslands. Tuexenia 2018, 38, 311-328. [CrossRef]

62. Chytrý, M.; Pyšek, P.; Tichý, L.; Knollová, I.; Danihelka, J. Invasions by alien plants in the Czech Republic: A quantitative assessment across habitats. Preslia 2005, 77, 339-354.

63. Celesti-Grapow, L.; Blasi, C. The Role of Alien and Native Weeds in the Deterioration of Archaeological Remains in Italy. Weed Technol. 2004, 18, 1508-1513.

64. Sudnik-Wójcikowska, B.; Moysiyenko, I. The synanthropic flora of kurgans within three steppe zones in southern Ukraine. Biodiv. Res. Conserv. 2008, 11-12, 41-48.

65. CICES-The Common International Classification of Ecosystem Services. Available online: https://cices.eu (accessed on 18 January 2022).

66. Matsler, M.; Meerow, S.; Mell, I.; Pavao-Zuckerman, M. A 'green' chameleon: Exploring the many disciplinary definitions, goals, and forms of "green infrastructure". Landsc. Urban Plan. 2021, 214, 104145. [CrossRef] 